\title{
The Decade 1989-1998 in Spanish Psychology: An Analysis of Research in Social Psychology
}

\author{
Amalio Blanco and Luis de la Corte \\ Autonomous University of Madrid
}

\begin{abstract}
In this study, a detailed exploration is carried out of the production of research and theory in social psychology in the Spanish context. The main research areas are: Work and organizational psychology, social health psychology, community and social services psychology, environmental research, judicial and political psychotogy, psycosocial theory and meta-theory, social psychology of language, research on emotion, group processes and social identity. The growing importance of social psychology within the framework of Spanish psychology is emphasized, and the relation with specific social problems from the national context, and the paradoxically scarce originality of the theoretical perspectives and the leading research, strongly influenced by Anglo Saxon social psychology, is commented upon.
\end{abstract}

\begin{abstract}
Este trabajo realiza una exploración pormenorizada de la producción de investigación y teoria sobre psicología social en el contexto español. Las áreas fundamentales de investigación son: psicologia del trabajo y las organizaciones, psicologia social de la salud, psicologia comunitaria y de los servicios sociales, investigación en medio ambiente, psicología jurídica y política, teoría y metateoría psicosocial, psicología social del lenguaje, investigación sobre emoción, procesos grupales e identidad social. Como conclusiones cabe destacar la importancia creciente de la psicología social en el entorno de la psicologia española, la vinculación con problemas sociales específicos del contexto nacional y la paradójica escasa originalidad de las perspectivas teóricas y de investigación pujantes, fuertemente influidas por los patrones de la psicologia social anglosajona.
\end{abstract}

Correspondence concerning this article should be addressed to Dr. Amalio Blanco, Facultad de Psicología. Departamento de Psicología Social y Metodología Universidad Autónoma de Madrid. Ciudad Universitaria de Cantoblanco. 28049 Madrid (Spain). E-mail: amalio.blanco@uam.es 
Although not the main purpose of this work, the reader is once more reminded of the Lewin's "extending the object" hypothesis, in order to defend a concept of social psychology as a special way to approach the study of specific events in which humanity has been interested since time began: love, altruism, aggression, power, and so on. Psychosocial events are seen as a series of concepts and related theories, a way to address the eternal topics, using an interactive, interdependent, and relational framework. To quote what is probably Vygotsky's most distinctive hypothesis (thus, reclaiming it as a framework for our discipline), psychosocial phenomena are definitely mediated phenomena.

At the beginning of The Historical Meaning of the Crisis of $P_{\text {Sychology, Vygotsky speculated that the development and }}$ decline of theories and concepts may be explained in connection with the sociocultural substratum of the times, the laws and conditions of scientific knowledge, and the demands of the phenomena studied, depending on their nature. This notion has been endorsed by the sociology of knowledge. Current historiography (see an excellent example in Rosa, Huertas, \& Blanco, 1996) is also within this framework: Psychology and social aspects make up a twofold social practice that occurs within a context. The framework of Spanish psychosocial research in the last decade derives from our context of intellectual orphanhood, resulting from the Civil War (1936-1939), which turned the Spanish scientific panorama into a desert. Not till the sixties could we observe in the psychosocial scenario the presence of three research topics of great tradition: the study of attitudes, in which Torregrosa was a pioneer, group behavior, and mass media (Blanco, 2000). And not till 1980 could we celebrate the first contact with European Social Psychology at the "First Encounter concening the Situation and Perspectives of Social Psychology in Spain," held in Barcelona, with the collaboration of the "Laboratoire Européen de Psychologie Sociale de la Maison des Sciences de l'Homme," directed by Moscovici. Till then, orphanhood and isolation were our fate.

But these are not the only antecedents of the decade that has just ended. Current Spanish psychosocial research would be incomprehensible unless we take into account the spectacular increase in the demand of psychology studies that began in the mid-seventies, along with massive access of faculty members who teach topies of this area in the university. We must also take into account the legal context defined by the Ley de Reforma Universitaria [University Reform Law] of 1983, which consolidated the position of a large number of university faculty members dedicated almost exclusively to teaching and research (at the deadline of the this review - 1999 - there are 34 full university professors, 127 tenured university professors, 9 full professors from the university school, and 22 tenured professors from the university schoob). We also acknowledge the institutional sensitivity to the need to adapt to the times, to new social needs and to the labor market requirements, as can be seen from the profound renewal of the study plans carried out in the last decade; and the considerable but insufficient impetus that the authorities began to award to research at the beginning of the eighties.

\section{Topic Areas and Research Trends}

This is the setting and framework of this study and they must be taken into account, because social psychology in Spain could be also portrayed in different terms, such as those used by Pinillos (1965), and also especially, by Jiménez Burillo (1976), who laid down the foundation (perhaps excessively linked to biographical events) to trace the history of social psychology in our country. He anticipated the spectacular growth of social psychology at the end of his work: "The rapid development of the social sciences in our country, and the already solid consolidation of our discipline within the university setting, enable me to predict the beginning of a new era during which we will probably observe the extension of Spanish social psychology in search of more ambitious goals" (Jiménez Burillo, 1976, p. 264). This is precisely the era on which we shall center our analysis.

When directly addressing the psychosocial production of the nineties, using the methodology described in detail in Femández (this issue) -using the international databases MEDLINE, PsycLIT, ERIC, and PSICODOC98- the extension of research interests developed under the label of social psychology is noteworthy: 23 investigations traditionally related with this discipline, and 6 of a more transverse nature (having similar application settings), as can be seen in Table 1.

These research interests corroborate the concept of psychosocial studies removed from territoriality (social psychology as a discipline characterized by the study of a series of specific topics), with distinctive concepts and levels of analysis. These research interests are of a level of generality that goes beyond that of research trend as considered in this special issue, based on the recommendations in Fernández (this issue). In fact, each of the areas includes several research trends. The title of each trend, especially the more representative ones (work and organizational psychology, health psychology, community psychology, environmental psychology, judicial psychology, and political psychology), shows that we are dealing with areas whose content can become -and in some academic settings, it already has- true training specialties. Within the strictly psychosocial areas, one could establish a twofold distinction: Some areas address the unavoidable applied vocation of social psychology (work and organizational psychology, health psychology, community psychology, environmental psychology, etc.), whereas others follow the prominent theoretical and basic research traditions within our discipline (social influence processes, group behavior, social identity, social foundation of emotion, or the ever-increasing interest in theoretical and meta-theoretical reflection on social psychology). Lastly, these data indicate 
Table 1

Research settings

\begin{tabular}{|c|c|c|}
\hline Research and Application Settings & Number of publications $(N=1553)$ & $\%$ \\
\hline \multicolumn{3}{|l|}{ Social Psychology } \\
\hline Work and organizational psychology & 253 & 16.29 \\
\hline Social psychology of health & 158 & 10.17 \\
\hline Community social services psychology & 99 & 6.37 \\
\hline Environmental psychology & 86 & 5,54 \\
\hline History of social psychology & 75 & 4.83 \\
\hline Judicial psychology & 72 & 4.64 \\
\hline Political psychology & 62 & 3.99 \\
\hline Processes of social influence & 60 & 3,86 \\
\hline Theory and method in social psychology & 56 & 3.61 \\
\hline Psychosocial proceses and gender processes & 49 & 3.16 \\
\hline Social psychology of language & 46 & 2.96 \\
\hline Social foundations of emotion & 40 & 2.58 \\
\hline Stereotypes, prejudices, and social discrimination & 32 & 2.06 \\
\hline Group and collective processes & 32 & 2.06 \\
\hline Conflict and negotiation & 31 & 2.00 \\
\hline Violence, aggression, and maltreatment & 30 & 1.93 \\
\hline Family and couple relations & 29 & 1.87 \\
\hline Social cognition, attribution and social representations & 27 & 1.74 \\
\hline Social identity & 25 & 1.61 \\
\hline Quality of life & 19 & 1.22 \\
\hline Cross-cultural psychology & 16 & 1.03 \\
\hline Mass communication media & 10 & .64 \\
\hline Others & 101 & 6.50 \\
\hline \multicolumn{3}{|l|}{ Settings with similar applications } \\
\hline Traffic psychology & 29 & 1.87 \\
\hline Sport psychology \& psychology of leisure & 28 & 1.80 \\
\hline Social gerontology & 28 & 1.80 \\
\hline Design and evaluation of programs & 23 & 1.48 \\
\hline Consumer psychology & 23 & 1.48 \\
\hline Ergonomics & 14 & .90 \\
\hline
\end{tabular}

that basic and applied research are necessarily complementary in psychosocial research; in fact, they reveal that basic and applied research are just two sides of the same coin, two ways to approach one reality.

Taking as reference the 23 topic areas more strictly related to social psychology, the overview of the decade that has just ended is reflected in Table 2.

These are the topic outlines that define, and the research interests that characterize Spanish social psychology. A glance at Table 3, in which are displayed, grouped by topics, the papers and communications presented at the last five National Congresses of Social Psychology will corroborate this. Except for the educational field, which is addressed in another article in this special issue, (see Sánchez-Miguel \& García-Sanchez) the seven most well-represented areas in the last congresses coincide perfectly, practically in the same order, as the research trends shown in Table 2.
Not all the topic areas will be reviewed here. In some cases, because of their scarce representation (cross-cultural psychology and mass media), and in others because the research trends are interrelated, with evident interdependency. For instance, history of social psychology, which would be divided into theory and method; psychosocial processes and gender, which, to a large extent, would be reduced to gender identity; the broad areas of stereotypes, attribution, and social representation, which provide theoretical framework to group processes, health research, and identity studies. Conflict and negotiation have been investigated in the Spanish psychosocial panorama preferentially within the setting of work and organizational psychology whereas violence and aggression come under community psychology, which also includes studies on the quality of life. All these factors reduce the overview of the areas we shall comment upon below. 
Table 2

Research Research Trends and Percentage of the Total Number of Publications

\begin{tabular}{|c|c|c|}
\hline Works on Social Psychology & Number (1408) & $\%$ \\
\hline Work and organizational psychology & 253 & 17.97 \\
\hline Social psychology of health & 158 & 11,22 \\
\hline Community social services psychology & 99 & 7.03 \\
\hline Environmental psychology & 86 & 6.11 \\
\hline History of social psychology & 75 & 5.33 \\
\hline Judicial psychology & 72 & 5.11 \\
\hline Political psychology & 62 & 4.40 \\
\hline Processes of social influence & 60 & 4.26 \\
\hline Theory and method in social psychology & 56 & 3.98 \\
\hline Psychosocial processes and gender processes & 49 & 3.48 \\
\hline Social psychology of language & 46 & 3.27 \\
\hline Social foundations of emotion & 40 & 2.84 \\
\hline Stereotypes, prejudices, and social discrimination & 32 & 2,27 \\
\hline Group and collective processes & 32 & 2.27 \\
\hline Conflict and negotiation & 31 & 2.20 \\
\hline Violence, aggression, and maltreatment & 30 & 2.13 \\
\hline Family and couple relations & 29 & 2.06 \\
\hline Social cognition, attribution and social representations & 27 & 1.92 \\
\hline Social identity & 25 & 1.78 \\
\hline Quality of life & 19 & 1.35 \\
\hline Cross-cultural psychology & 16 & 1.14 \\
\hline Mass communication media & 10 & .71 \\
\hline Others & 101 & 7.17 \\
\hline
\end{tabular}

\section{Work and Organizational Psychology}

As seen in Table 1, the first and most extensive research area refers to the work and organizational psychology setting. This area "has experienced a pronounced development in our country during the nineties [...], which, although not exempt from imbalance, tension, insufficiencies, and maladaptations [...], is the most important produced in the $20^{\text {th }}$ century" (Peiró \& Munduate, 1999, p. 372). The first research trends were developed under the direction of Peiró. First, is research strictly related to organizations, where two classical research trends can be identified: (a) one on work satisfaction (Gracia, Ramos, \& Peiró, 1996), with special focus on health professionals (Peiró, González, Zurriaga, Ramos, \& Bravo, 1990; Zurriaga, Bravo, \& Peiró, 1990); and (b) a second trend on organizational management, specifically the management of sports facilities and touristservices organizations (Peiró \& Ramos, 1995, Peiró et al., 1997; Ramos, Peiró, \& González, 1993). To these, we must add the study of work stress, where researchers have also addressed environments directly or indirectly related to health (Gil-Monte \& Peiró, 1998; Gil-Monte, Peiró, \& Valcárcel, 1996), prevention of labor risks, where the research trend by Meliá (Meliá, Arnedo, \& Ricarte, 1996; Meliá, Sospedra, \& Rodrigo, 1994) is noted. In other cases, social psychology is linked to a new social phenomenon such as the implementation of new technologies (Prieto, Zornoza, \& Peiró, 1997), where the work carried out by Torre (1997, 1998 ) is noteworthy.

Regarding the problem of employment and unemployment, the area of social psychology of work offers three more research trends, most of them mainly interested in the relations of unemployment in the youthful population. These works seem to acknowledge that, even in young people, unemployment causes some decrease in psychological well being (Álvaro, 1992; Blanch \& Salleras, 1990; Garrido Luque \& Álvaro, 1992; Hontangas, Moret, Peiró, \& Balaguer, 1990), according to various reliable indexes. Some of these researchers have also observed that there are various psychological characteristics (attributional style, social comparison tendency, repertory of daily activities, etc.) that may condition young people's likelihood of working or willingness to work (Blanch \& Salleras, 1990).

In the extensive field of organizational efficacy (Fernández-Ríos \& Sánchez-García, 1997) is a research trend by Prieto, focusing on processes to evaluate posts and tasks, recruitment, personnel selection and training, and performance evaluation (Prieto, 1993) with special attention on person-to-job adaptation, the role of age-related individual differences, and personnel aging in work settings (Forteza 
Table 3

Communications and Papers Presented in Various Topic Areas in the last Five Social Psychology Congresses

\begin{tabular}{|c|c|c|c|c|c|}
\hline Topics & $\begin{array}{c}\text { Alicante } \\
\text { (1988) }\end{array}$ & $\begin{array}{c}\text { Santiago } \\
(1990)\end{array}$ & $\begin{array}{l}\text { Sevilla } \\
\text { (1993) }\end{array}$ & $\begin{array}{c}\text { Salamanca } \\
(1995)\end{array}$ & $\begin{array}{c}\text { San Sebastián } \\
(1997)\end{array}$ \\
\hline Work and organization psychology, psychology of unemployment & 22 & 21 & 44 & 62 & 35 \\
\hline Social psychology of health & 17 & 15 & 34 & 28 & 16 \\
\hline Community psychology & 10 & 17 & 25 & 19 & 11 \\
\hline Educational psychology & 17 & 11 & 23 & 18 & 8 \\
\hline Environmental psychology & 8 & 14 & 12 & 14 & 15 \\
\hline Political psychology & 17 & 9 & 15 & 12 & 14 \\
\hline Judicial psychology & 7 & 4 & 21 & 13 & 7 \\
\hline Social psychology of sports, leisure, and tourism & 9 & 6 & 6 & 17 & 14 \\
\hline Psychology of communication and marketing & 9 & 4 & 18 & & \\
\hline Basic psychosocial processes & 5 & 9 & 20 & 19 & 10 \\
\hline Social psychology of groups & 8 & 4 & 13 & 23 & 12 \\
\hline Epistemology & & 4 & 6 & 8 & \\
\hline Social psychology of language & 10 & 2 & & & 4 \\
\hline Social and cultural identity & & & 13 & & 10 \\
\hline Psychosocial perspectives in cognition and emotion & & 6 & & & 14 \\
\hline Attitudes, beliefs, and social values & & & & & 12 \\
\hline Affective relations and pro-/ anti-social behaviors & & & & & 7 \\
\hline Social influence & & & & & 4 \\
\hline Intergroup prejudices and stereotypes & & & & & 26 \\
\hline Cross-cultural social psychology & & & & & 5 \\
\hline Social movements & & & & & 7 \\
\hline Social and collective memory & & & & & 6 \\
\hline Psychosocial well being & & & & & 13 \\
\hline Gender relations & & & & & 13 \\
\hline Individualism - collectivism & & & & & 6 \\
\hline
\end{tabular}

\& Prieto, 1994), and the implications of the new information technologies in processes of personnel evaluation (Prieto \& Simón, 1997). A research trend by Salgado centers on personnel selection, in which, in addition to advancing the "Five-Factor Personality Inventory" (Salgado, 1998), has shown how two of the important personality factors (consciousness and emotional stability) predict job performance in any profession (Salgado, 1997; Salgado \& Rumbo, 1997).

We must also refer to two more research trends: the study of conflict and of organizational culture. The first trend has been addressed in practically all its facets: In negotiation and mediation, the work performed by Fernández-Ríos (Fernández-Ríos, 1989, 1997; FernándezRíos, Rico, \& Rascado, 1999) is noteworthy. Conflict management styles has been studied by Munduate, (Ganaza, Munduate, \& Peiró, 1995; Munduate, Ganaza, \& Alcaide, 1993; Munduate, Luque, \& Barón, 1998), and Serrano, while not ignoring any of these fields, has focused preferentially on collective negotiation (Rodríguez \& Serrano, 1991), and more particularly, on attitudes in the labor negotiation process (Serrano \& Remeseiro, 1990).
The topic of culture and socialization in organizations is a broad chapter in this area that we cannot review in depth (see Peiró \& Munduate, 1999). However, we do note a research trend, developed primarily on the strategies by means of which organizations socialize their members (Palaci, Osca, Grau, \& Bravo, 1995; Palací, Osca, \& Ripoll, 1995); in other words, the transmission of a system of rules, values, and relation styles that make up an organizational culture. This is an area in which many investigations converge, in some cases, with the aim of delimiting the concept of climate (Rodríguez, 1990, 1993; Silva, 1992, 1994) and, in others, to study the relation between climate and leadership styles (Alonso, 1993) -a classical social psychology pairing- or to study climate and leadership styles in professional services organizations (Alonso, Palací, \& Osca, 1993; Osca, Alonso, \& Palací, 1995; Rodríguez, 1993).

\section{Social Psychology of Health}

The concept of health as more than the mere absence of illness and the intimate conceptual relationship of health with physical, social, and psychological well being lends a 
privileged position to social psychology when addressing the study of these topics. The incorporation of Spanish social psychology into the study of health dates from the early eighties (Huici, 1982) but it is not until the end of that decade that real research trends, as defined in this issue, appear. The first trend is led by Rodríguez Marín about various coping styles when faced with hospitalization (Rodríguez Marín, López, \& Pastor, 1989). Nevertheless, the study of chronic pain is doubtless the most fruitful psychosocial research trend. Some studies focus on perception of pain and coping styles in rheumatic patients (Pastor et. al., 1989, 1990; Pastor, López, Rodríguez-Marín, Terol, \& Sánchez, 1995), or in patients suffering from fibromyalgia syndrome (Pastor et. al., 1993) and others, on examining on the relation between chronic pain and social support (Pastor et. al., 1994). Social support is also studied within the hospital setting as a mediating mechanism in hospitalized patients' recovery, a topic also addressed by the research group of Rodriguez Marín et al. (López, Sánchez, Pastor, \& Rodríguez-Marín, 1990; RodríguezMarín, Pastor, \& López, 1993).

In Spain, the study of social representations-a central topic in European social psychology-related to health and illness began in the mid eighties (see the empirical research by Itza, Pinilla, \& Páez, 1987) and since then, it has become one of the most solid research trends within the health setting. And, inevitably, AIDS has become the meeting point of many trends (Basabe, Páez, Usieto, Paicheler, \& Deschamps, 1996). The study of individuals' knowledge about AIDS and how it is transmitted, its characteristic representations and associated beliefs, and the attitudes that individuals generate about persons suffering from AIDS, as well as behavioral strategies to prevent infection are all being studied by other research group (Echebarría \& Páez, 1989b; Echebarría, San Juan, \& Ozmiz, 1992; Páez, Echebarría, et al., 1991; Páez, San Juan, Romo, \& Vergara, 1991; Páez, Ubillos, \& León, 1996). The guiding hypothesis is that people will adjust their preventive behavior on the basis of culturally provided prototypical scenarios, by means of activation of ideology-based molar representations (Páez, Ubillos, \& Paichelier, 1994). This hypothesis is reinforced in studies of the prototype of person who becomes infected with a specific illness and the typical cause of infection (Blanco, Páez, Penín, Romo, \& Sánchez, 1993; Sánchez, Romo, Páez, Blanco, \& Lalljee, 1996), which is usually revealed as a feeling of invulnerability (illusory optimism) and is manifested as an unjustified low perception of risk (Sánchez, Rubio, Páez, \& Blanco, 1998).

The research trend carried out under the direction of Barriga and León $(1990,1991)$ is also noteworthy when referring to health within the Spanish social psychology context. With regard to specific research trends, we note the trends related to social skills assessment and training (Gil, León, \& Jarana, 1995), to improve social competence in the mentally retarded (Ojeda, Pérez, Jarana, \& León, 1989), in blind people or in people with visual deficiencies (León \& Medina, 1994; Medina \& León, 1995), or to provide health professionals with social skills in order to perform their professional role (León, Jarana, \& Blanco, 1991; León et al., 1997; Negrillo, Tirado, \& León, 1994). See Sanz (this issue) for mote information about psychology of health in Spain.

\section{Community Social Services Psychology}

We can distinguish some research trends that have the aim of intervention in community. The first one focuses on social support, understood as the influence of social networks on people's well being, by means of reducing the consequences of stressful events on mental health, like a central mediator in social intervention strategies (Gracia, 1997). Here, we have included the research trend initiated by Barrón (Barrón, 1996; Barrón \& Chacón, 1990, 1992) and the one by Gracia: social support as a resource for psychological and social adjustment (Gracia, Herrero, \& Musitu, 1996; Herrero \& Musitu, 1998), for physical, social, and psychological well being, as well as the potential relevance of social support as a mediating variable between stress and psychological adjustment in families with childmaltreatment problems (Gracia \& Musitu, 1997; Gracia, Musitu, Arango, \& Agudelo, 1995).

From the framework of social indicators and social politics, Casas has examined the indicators of quality of life (Casas, 1997), of social hazards in infancy (Casas, 1989), and of boarding children with surrogate families as a possible solution (Casas \& Durán, 1996).

On the basis of his doctoral dissertation about altruistic behavior, Chacón has addressed the psychosocial factors that affect volunteers (Chacón, Menard, Sanz, \& Vecina, 1998), volunteers' tendency to remain in warfare situations (Chacón, 1999), butnout experienced by individuals from this collective (Chacón \& Vecina, 1999).

A last research trend focuses on the study, phenomenology, and psychosocial mediators of high-risk behaviors, such as intergroup violence (Martín, Martínez, López, Martín, \& Martín, 1998), consumption of alcohol and illegal drugs, dangerous driving, and risky sexual behavior (Martín \& Martinez, 1998). This group is also working on a trend to identify and measure the psychosocial variables that affect the attitudes of the Spanish population concerning organ donation and transplantation (Martín, Martínez, \& López, 1995; Martín, Martínez, \& Manrique, 1991).

\section{Environmental Psychology}

For social psychologists, the Lewinian concept of behavior as a result of interdependent relations between the person and the environment is an unquestionable historiographical axiom. This clears the path to research about the physical environmental factors, not only as a framework of behavior, but as determinants or instigators of behavior. The 
first approximation by Spanish social psychology in this field was observed in Psicología y medio ambiente [Psychology and Environment], a book coordinated by Jiménez Burillo in 1982, followed by a second one, of a more psychosocial nature (Jiménez Burillo \& Aragonés, 1986), in which appear the central topics of this field: cognition and environmental perception, cognitive maps, the effect of noise, environmental stress, responsible ecological behavior, etc. Since then, the field of environmental psychology has been one of the big issues in Spanish social psychologists' concerns. This interest is not limited to the field of research, but also takes the form of a remarkable rise in teaching in Psychology Departments, and the celebration of the VII National Congress, which indicate the force with which environmental thought has appeared on the Spanish scientific scene, from the psychological viewpoint.

Taking as a framework the recent review by García Mira (2000), the research trends in this field follow a broad tradition in the study of urban environments (Corraliza \& Aragonés, 1993), in dimensions such as knowledge and representation of cities, the meaning attributed by citizens to the elements that define and characterize these cities, and the evaluation of urban scenery. Residential environments constitute a second research trend, within the setting of a very specific interest, that of residential satisfaction (Amérigo \& Aragonés, 1990, 1997; Aragonés \& Corraliza, 1992), the most outstanding approach to which is doubtless the research carried out by Amérigo (1995). Along these lines, Hernández (Hernández, Correa, \& Camacho, 1992; Hernández \& Suárez, 1994), has made several noteworthy contributions. In the last decade, intervention and environmental management have also been a clear concern of Pol (Pol \& Moreno, 1994; Pol \& Vidal, 1996), a pioneer in the psychosocial study of environment.

In the last decade, researchers have focused on topics related to natural environment. ("green" environmental psychology), a recent research trend, coordinated by Corraliza (1998).

\section{Judicial Psychology}

There are various topic areas in research on judicial psychology. First, some noteworthy programs are aimed at increasing problematic adolescents' social competence, this preventing their entry into a future "crime career." Cognitive behavioral treatment seems to produce significant results, even in short interventions (about 40 hours), considerably improving subjects' capacity to reflect and to play a role, as well as their intellectual problem-solving skills.

In a second trend, researchers attempt to explore the feasibility of applying some of the main persuasion models to the judicial environment. Their data confirm the persuasive importance of certain peripheral cues of eyewitnesses, independently of the content of their statements, for instance, their physical attraction or status, or their rhetoric abilities (Sobral \& Prieto, 1993). However, a jury meets all the necessary criteria to be considered a group, and, inevitably, decisions about the innocence or guilt of an accused person have preferentially attracted the attention of other group of social psychologists (Arce, Fariña, \& Real, 1998; Arce, Sobral, \& Fariña, 1990). The level of variability in the assignment of prison terms by $S$ panish judges was also analyzed. This group found enormous differences in the severity of sentences as a function of various aspects, all associated with judges' different beliefs or "penal philosophies" (Sobral, 1994), based on their level of experience (Paúl, 1996), their ideology (Sobral, Arce, Fariña, \& Vilán, 1991), and even taking into account their inferential biases (Arce, Fariña, \& Sobral, 1995). In addition to theoretical reflections about the delimitation and nature of judicial psychology has developed a research trend about a topic of broad social impact: judicial sentences for sexual crimes (Garrido, 1995; Garrido \& Herrero, 1996).

Also within judicial psychology are the noteworthy works on violence by Clemente. He sometimes studies violence in relation to the change of values in Spanish society (Clemente, 1998) and other times, focuses on the influence of television on children's violent behavior (Clemente \& Vidal, 1994), or the specific ways in which violence is carried out, for example, sexual violence (Clemente \& Fernández, 1994).

\section{Political Psychology}

When Sabucedo reviewed the field of political psychology in Spain, he lent support to our orphanhood hypothesis, mentioned at the beginning of this article. Despite the works in this field, in some cases going back to the $19^{\text {th }}$ century, and even to the closer seventies (Torregrosa, 1971), one cannot say that current Spanish political psychology is based on those authors, "our thesis is that those works [...] had no influence on the current political psychology" (Sabucedo, 2000 , p. 185). In fact, what is currently the field of political psychology in Spain is a direct consequence of what occurred in the teaching area (introduction of political psychology as curricular content in the University of Santiago de Compostela in 1983), the institutions (I Congress of Political Psychology in 1987, creation in 1990 of the Revista de Psicología Politica [Journal of Political Psychology]), and because of the publications mentioned in Sabucedo's review.

As in other areas, in political psychology we can also find several research trends about the same topic. This is seen clearly, for example, in the case of the studies on political participation and its various psychosocial conditioners. Of special interest is the study of unconventional or noninstitutionalized means of political participation (Sabucedo, 1989), which range from signing a protest note or participating in a legal demonstration, to participating in a strike, occupying a building, or committing an aggression. These actions, arranged in decreasing order of occurrence, may correlate directly with their perceived efficacy (Sabucedo, Arce, \& Rodriguez, 1992). Other authors have noted the influence of several psychosocial variables (collective and social motives, 
amount of interest in politics, reward motives, social class, anomia, degree of ideologyzation, social identity, according to Valencia, 1990) in a person's willingness to become involved in unconventional ways of political participation.

In another trend, the attempt has been made to identify the population's attitude about new social challenges and the way they are reflected in the structure and content of collective beliefs about certain issues, such as new environmental values, family and its relation to beliefs and political participation (Garzón, 1998).

In the nineties, social movements were the principal object under study within the sphere of Spanish political psychology (Sabucedo, Grossi, \& Fernández, 1998; Valencia, 1990).

Lastly, processes of collective violence have given rise to two research trends. The first one studies the causes and possible alternatives to war or high-intensity conflicts, emphasizing the transcendence of warlike socialization processes and conflictrelated factors (Moreno, 1991). The second one addresses images and categorization processes that occur in situations of collective strife (Herrera \& Reicher, 1998).

\section{Processes of Social Influence}

The most distinctively psychosocial phenomena converge in the issue of social influence, simply because "influence phenomena refer to the processes by which, in the course of direct or symbolic social interactions, individuals and groups originate, maintain, extend, and modify the way they think and behave" (Pérez \& Mugny, 1988, p. 1). On the basis of this assumption, Pérez has studied an extensive series of phenomena: from minority influence (Pérez \& Mugny, 1990; Roux, Mugny, \& Pérez, 1989) to the so-called phenomenon of validation, a psychosocial process by which a minority influence is generated. Subsequently, he has studied conflict (Pérez, Falomir, \& Mugny, 1995), discrimination, prejudice, and racism (Moscovici \& Pérez, 1997; Mugny, SánchezMazas, Roux, \& Pérez, 1991), in addition to the effect of influence on certain addictive behaviors (Falomir, Mugny, \& Pérez, 1996; Pérez \& Mugny, 1992).

Together with works based on the paradigm of minority social influence, we find a second research trend referring to the domain of rules or, more specifically, to what a group of Spanish researchers has called "perverse rules" (Fernández-Dols, 1993). This expression refers to a specific type of coercive rules that are broadly accepted but which, for some reason, people tend to transgress in a generalized manner. The perversity of these rules does not come from the rules themselves but from their social consequences, that is, demoralization and corruption. The term "demoralization" is used here to refer a common tendency to discredit or "dislegitimize" persons who, from a position of authority, try to make others obey a coercive rule that is generally transgressed. On the other hand, as seems corroborated in some laboratory situations designed by this group of researchers, a perverse normative structure can generate comption because it foments authorities' favoritism regarding the irregular and partially arbitrary application of these rules (Fernández-Dols \& Oceja, 1994).

\section{Theory and Meta-Theory in Social Psychology}

In the last few decades, Spanish social psychology has echoed Anglo-Saxon social psychology. One of the most outstanding aspects has been the scarce interest in theoretical and epistemological reflection, along with the uncontrolled reproduction of empirical studies, often carried out in a deplorable social vacuum, but claiming to be closely related to methodological artifacts, and at the same time completely ignoring the socio-historical context in which they are generated.

Meta-theoretical reflection in the last decade by social psychologists follows the line that Ibáñez (1990, p. 143-146) made explicit in his criticism of the accumulativeness, in the immeasurableness, and refutability that have characterized psychosocial theory and research carried out from the framework of logical positivism. This line of thought was followed by Torregrosa (1996), Munné (1997, 1999), Jiménez Burillo (1997), and Ovejero (1991) in various critical and meticulous analyses of meta-theoretical assumptions (epistemological, ontological, and methodological) of the discipline. From different viewpoints, all these authors express their opposition, or at least strong skepticism, to the hegemonic neo-positivist tradition of research and theoretical development, which still considers the experiment as the only sure path to rigorous scientific knowledge and which still rejects the well-founded reproaches aimed at the discipline, from that time of crisis.

Actually, instead of a united opposition to hegemonic social psychology, reference should be made to many fronts and various strategies for improving the course of the discipline or at least for creating their own traditions and theoretical focuses, thus extending the area of topics, problems, and research methods. Doubtless, the most numerous and influential works in this sense are those carried out by the group led by Ibáñez (1990, 1994, 1997). This group has an extensive research trend on the critical analysis of social psychology, which has evolved toward postmodern positions similar to Gergen's social constructivism, with special interest in the development of a social psychology of scientific knowledge (Domènech \& Ibáñez, 1998; Ibáñez \& Îniguez, 1996).

The sense of criticism of the actual state of affairs of the discipline has also produced much historiographic research. One of the obvious aims coincides with other attempts to rethink social psychology in the light of classical authors such as Mead, Lewin, or Vygotsky (Blanco, 1996), or of Spanish thinkers such as Ortega y Gasset, first introduced in Spanish social psychology by Torregrosa (1985), and followed by Ovejero (1992) and Corte (1997), and of outstanding figures from the recent history of social psychology such as MartínBaró, one of the Jesuits who was assassinated in El Salvador in 1989 (Blanco, 1998; Corte, 1999). 
Social Psychology of Language

Constitutional sanction of the unquestionable historical fact of the existence of differentiated linguistic communities in Spain cleared the way for the study of language in traditional social psychology topics. And for obvious reasons: In addition to an eminently social behavioral reality, language is a sign of linguistic and cultural identity, an indicator of comparative identity (Huici \& Ros, 1993), a process of specific self-categorizing associated with certain representations and stereotypes in turn related to intergroup processes. These psychosocial topics are undoubtedly enriching.

Within this context, there are two clear research trends: the one carried out by Azurmendi within the context of Euskera-Spanish linguistic contact, and the one by Ros, more related to group processes of cultural and linguistic identity. Research by both Romay and González (within the bilingual Gallician-Spanish and Catalan-Spanish contexts, respectively) can be sporadically added to these trends.

The first research trend is based on clearly psycholinguistic and sociolinguistic assumptions, producing psychosociolinguistics as "a result of the process of interdisciplinarization directed from and at social psychology" (Azurmendi, 1999, p. 17), and which is preferentially concerned with linguistic behavior in situations of contact between languages (Azurmendi, 1995). The second trend has focused on language as an indicator of social identity, a sign of group identity in bilingual contexts (Ros, Cano, \& Huici, 1987; Ros, Huici, \& Cano, 1990).

However, both trends have converged in the last few years in the ICALABE-1996 Project ("Identidades Culturales y Lingüísticas en la Comunidades Autónomas Bilingües de España" [Cultural and Linguistic Identities in the Bilingual Autonomous Communities of Spain]) with the aim of studying cultural and linguistic identities related to: (a) beliefs about the ethnolinguistic vitality of languages and of linguistic groups in contact with each other; (b) the individual network of linguistic and cultural contacts; (c) the competence level and use of languages in contact with each other; (d) intergroup relations: intergroup attitudes, social distance, discrimination, cooperation, and tension; (e) concepts of citizenship (Azurmendi, Bourbis, Ros, \& García, 1998; Ros, Azurmendi, Bourhis, \& García, 1999).

\section{Social Foundations of Emotion}

Similarly to social influence, within the context of Spanish social psychology, the study of emotional behavior (Femández-Dols \& Ortega, 1985) first attracted researchers' interest in the mid eighties and has continued to do so led by Fernández-Dols (Russell \& Fernández-Dols, 1997), based on experimental methodology.

The framework of this research is made explicit in a chapter entitled "Facial expression and context: Towards an ecology of emotional expression; Context as a Key Concept" in which the authors state: "if we briefly consider all the most important problems and achievements in the study of meaning and facial expression of emotion, we would realize that all of them have one concept as their key reference point: context" (Fernández-Dols, Carrera, \& Mallo, 1989, p. 403). Context has provided a framework for the meaning of facial expression (Carrera \& Fernández-Dols, 1994) and of recognition of emotion (Fernández-Dols, Sierra, \& Ruiz-Belda, 1993).

A fairly original research trend related to emotions is the phenomenon of lies. A group of researchers has studied the possibilities of detecting lies by means of the analysis of patterns of emotional expression and of verbal and nonverbal behavior: physiological arousal level and its facial correlates, pupillary dilation, etc. (Becerta \& Sánchez, 1989). These authors have also carried out a series of investigations about the knowledge of prototypical lie-situations in everyday life (Sánchez, Becerra, Caballero, \& Amate, 1995).

We cannot conclude this section without mentioning the research trend on emotions led by Echebartía and Páez (1989a), in an attempt to overcome social constructivism and symbolic interactionism, by means of socio-historical theory (Adrián, Páez, \& Álvarez, 1995; Páez \& Adrián, 1993). The central hypothesis of this trend is that commonsense knowledge of emotions is closely related to sex, gender identity, and cultural values (Páez \& Vergara, 1995).

\section{Group and collective processes}

The study of group behavior has made up a continuous research trend in Spanish social psychology ever since the seventies, and in the last decade, it seems to have acquired special protagonism, to judge by the proliferation of monographs and manuals about the topic (Ayestarán, 1996; González, 1995, 1997; López-Yarto, 1997). Although they are clearly related to teaching, they nonetheless indicate the growing interest in this topic among Spanish social psychologists.

Focusing on the setting of this article, a first research topic on groups is about leadership. From the perspective of the socalled charismatic leadership, issues such as the differential gender traits of a person who gains access to posts of responsibility in training organizations, the relation between charisma and certain cultural variables, and the efficacy of this type of leadership in Spanish business and health organizations have been identified (López-Zafra \& Morales, 1999; Morales \& Molero, 1995). Another of the most important trends and investigation topics in this area is training and formation of leaders (Gil, Rodríguez-Mazo, \& Alcover, 1998).

However, the protagonists of the most fruitful research trend in the area of group behavior are no doubt the sociocognitive variables, along the lines of the School of Bristol, led by Tajfel. Socio-cognitive variables have sometimes been used to study identity in general (Echebarría \& González, 1993; Marqués, Abrams, Páez, \& Martínez-Taboada, 1998; Páez, Arróspide, \& Martínez-Taboada, 1992) and, more particularly, gender identity (Echebarría, 1992). At other times, 
socio-cognitive variables have provided the theoretical framework for intergroup differentiation, under the concept of "comparative identity" to which we referred in the section on social psychology of language (Huici \& Ros, 1993; Ros, Huici, \& Cano, 1990), in order to "evaluate the comparison process of two or more social identities that vary in their degree of inclusion." In addition to these studies of intergroup relations is the research trend by Rodriguez. He started with implicit theories, went on to analyze stereotypes and, subsequently, relations and intergroup conflict (González \& Rodríguez, 1994; Morera \& Rodríguez, 1994, 1997; Rodríguez, 1994).

Among the practical applications of the group techniques is the increase of discussion groups as an investigation and intervention procedure in various problematic settings, for instance, groups of violent youth, basically "ultra" sports fans and extreme rightist or neo-nazi groups (Fernández Villanueva, 1998), or subordinates or superiors in organizations (Abril $\&$ Musitu, 1995). Among the solid and continued applied research areas are also cooperative learning (Ovejero, 1996) in the educational setting, work programs in primary-attention teams (Peiró \& González, 1990), and conflict management (Ayestarán \& Reoyo, 1998).

\section{Social Identity}

To delimit the study of identity to research on group phenomena is not always easy, especially if, as noted above, many of the works on groups were inspired in Tajfel's model. However, the context in which the studies on identity in our country were carried out have a decidedly macro-social framework. They focus preferentially on the growing interest in national identities, and, to a lesser extent, gender identity.

Given that Spain is a pluri-national state, the topic of national identity and nationalism is a necessary reference point that is inevitably parallel to political psychology. In this field, several research trends wete identified, within the conceptual framework of national and regional stereotypes, a field in which several research groups are working (Javaloy, Cornejo, \& Bechini, 1990; Rodríguez, Sabucedo, \& Arce, 1991; Sangrador, 1996). However, in addition to the study of stereotypes we found some works directly related to national identity, both in more general aspects (Ovejero, 1997; Sabucedo, \& Fernández, 1998) and in concrete aspects of the "historical" nationalities: the Basque Country (Valencia \& Villarreal, 1992), Catalonia (Vivas, Muñoz, \& Îñiguez, 1997), and Galicia (Sabucedo, Arce, \& Rodriguez, 1992). Two more research trends should also be mentioned, which examine the processes of preservation of collective memory of various political events. Thus, some authors have studied mental narratives of the history of Spain and have shown how citizens conspicuously condition the content of these narratives accotding to their various political ideologies (Rosa, Blanco, Travieso, \& Huertas, 1999). More specifically, ideology affects not only interpretations of the national past, but also evaluation of the present, and future collective prospects.
In an attempt to recover and operationalize Halbwach's social memory hypotheses, a research trend was carried out under two basic assumptions: the normative nature of memory and its role in the defense of social identity. The biases of positiveness and consistency of informal recall of the collective past (Páez, Insúa, \& Vergara, 1992) are associated with these assumptions. Apparently, according to the findings of this research group, social identity is associated with memory and selective oblivion of historical facts, so that potentially contrary social identities, such as "national-Spanish" and "ethnic-Basque," determine the type and the meaning of recall of decisive historical events (Pennebaker, Páez, \& Rimé, 1997).

A research trend on gender identity, somewhat disperse in its authorship but of notable relevance within the context of Spanish social psychology should also be mentioned. It is interesting to note that the studies on gender, with 19 publications, take the first place in articles published by the Revista de Psicología Social [Joumal of Social Psychology] until 1999. López has worked on a research trend preferentially focused on stereotypes and gender identity, based on Tajfel's theoretical framework of social categorization (López, 1993, 1994; Morales \& López, 1994), which is common to Spanish social psychology. At times, López ventures into the topic of intergroup comparison: gender identity "as a modulating variable in the cognitive processes related to the categories of 'man' and 'woman'" (López, 1993, p. 190).

\section{Concluding Remarks}

Spanish social psychology from the last decade is its own child, the orphan of the history of Spanish thought, having adoptive parents. It has repeatedly seen itself reflected in AngloSaxon social psychology and, to a lesser extent, in some of the theoretical traditions of European social psychology. Despite this, the presence of this discipline in the academic panorama - seen in terms of the number of professors dedicated to teaching social psychology, the amount of periodical publications (Revista de Psicologia Social [Journal of Social Psychology], Revista de Psicologia Social Aplicada [Journal of Applied Social Psychology], Revista de Psicología Política [Journal of Political Psychology], Revista de Psicología del Trabajo y de las Organizaciones [Journal of Work and Organizational Psychology], Intervención Psicosocial [Psychosocial Intervention], Interacción Social [Social Interaction] - this last one has disappeared), the number of research trends, and even the amount of congresses and scientific meetings-- places Spanish social psychology among the foremost in the European ranking, at least in numeric terms.

But this expansion has not been able to interrupt, as would have been expected and desirable, the traditional isolation that social sciences in Spain have undergone. Despite its enormous potential, Spanish social psychology is still lost in thought, with little presence on the international 
scene, although its sources and frameworks have been, and still are, outside of our frontiers. This is seen clearly in the fact that out of the 218 references mentioned in this article, only 38 are published in English.

Summing up, we can come to two basic conclusions in our analysis about the state of Spanish social psychology in the last decade, which are naturally inter-related. First, as is prescriptive in the area of social sciences, the content of this social psychology is the outlines of "representative sample" of the series of issues that concern Spanish society, for instance, the realm of labor, health, ecological risks, political conflicts, national identity, or the current situation of women in our country. Nevertheless - and this is the second conclusion - there has been alarmingly little originality in the field of research and in generation of theories that should go together with research, as a consequence of the hasty and unthinking acceptance of theoretical, epistemic, and methodological assumptions imported from the predominant social psychology of Anglo-Saxon origin.

\section{References}

Abril, J., \& Musitu, G. (1995). Propuestas de acción participativa en la resolución de los conflictos organizacionales mediante la utilización de los grupos de discusión: un acercamiento desde el marketing social. In J.A. Conde \& A. Isidro (Comps.), Psicologia comunitaria, salud y calidad de vida (pp. 219-230). Madrid: Eudema.

Adrián, J.A., Páez, D., \& Alvarez, J. (1995). Art, emotion and cognition: Vygotskian and current approaches to musical induction and changes in mood, and cognitive complexitation. Psicothema, 8, 107-118.

Alonso, E. (1993). Liderazgo y cultura en las organizaciones: la perspectiva cultural del liderazgo. In L. Munduate \& M. Barón (Comps.), Psicologia del trabajo y de las organizaciones (pp. 67-76). Sevilla: Eudema.

Alonso, E., Palací, F., \& Osca, A. (1993). Una tipología de la cultura organizacional en centros de salud de la comunidad de Madrid. In L. Munduate \& M. Barón (Comps.), Psicología del trabajo y de las arganizaciones (pp. 45-54). Sevilla: Eudema.

Álvaro, J.L. (1992). Desempleo y bienestar psicológico. Madrid: Siglo XXI.

Amérigo, M. (1995). Satisfacción residencial. Un análisis psicológico de la vivienda y su entorno. Madrid: Alianza.

Amérigo, M., y Aragonés, J.I. (1990). Residential satisfaction in council housing. Joumal of Environmental Psychology, 10, 313-325.

Amérigo, M., A Aragonés, J.I. (1997). A theoretical and methodological approach to the study of residential satisfaction. Joumal of Environmental Psychology, 17, 47-57.

Aragonés, J.I., \& Corraliza, J.A. (1992). Satisfacción residencial, Psicothema, 4, 329-341.

Arce, R., Fariña, F., \& Real, S. (1998). Jurados: de su composición y sus efectos en la toma de decisión grupal. Revista de Psicologia Social, 13, 369-376.
Arce, R., Fariña, F., \& Sobral, J. (1995). Construcción estadística de perfiles predictores de sesgo en la formación de juicios. Revista de Psicología Social, 10, 3-16.

Arce, R., Sobral, J., \& Fariña, F. (1990). Hacia un modelo descriptivo/explicativo de la toma de decisiones grupales: el ejemplo de los jurados legos. Boletín de Psicología, 29, 87 96.

Ayestarán, S. (Ed.). (1996). El grupo como construcción social. Barcelona: Plural.

Ayestarán, S., \& Reoyo, A. (1998). Culture, styles of conflict management and identification in woks teams. Paper presented at the $11^{\text {th }}$ Annual Conference of the International Association for Conflict Management. Maryland.

Azurmendi, M.J. ( 1995). Relaciones entre las lenguas, los hablantes y la educación. Propuestas de contenidos. Paper presented at the XII Congress of Basque Studies in the Educational System. San Sebastián, Spain: Sociedad de Estudios Vascos.

Azurmendi, M.J. (1999). Psicosociolingïistica. Zarautz, Spain: Servicio Editorial de la Universidad del País Vasco.

Azurmendi, M.J., Bourhis, R., Ros, M., \& García, I. (1998). Identidad etnolinguíistica y construcción de ciudadanía en las Comunidades Autónomas bilingües de España. Revista de Psicología Social, 13, 559-589.

Barriga, S., \& León, J.M. (Eds.). (1990). Psicología de la salud. Aportaciones desde la Psicologia Social. Sevilla: Alfar.

Barriga, S., \& León, J.M. (1991). Psicología de la salud: aportaciones desde la Psicología social. Encuentros en Psicología, 18, 27-31.

Barrón, A. (1996). Apoyo social. Aspectos teóricos y aplicaciones. Madrid: Siglo XXI.

Barrón, A., \& Chacón, F. (1990). Efectos directos y protectores frente al estrés del apoyo social. Investigaciones Psicológicas, 8, 197-206.

Barrón, A., \& Chacón, F. (1992). Apoyo social percibido: su efecto protector frente a los acontecimientos vitales estresantes. Revista de Psicología Social, 7, 53-59.

Basabe, N., Páez, D., Usieto, R., Paicheler, H., \& Deschamps, J.C. (1996). El desafio social del SIDA, Madrid: Fundamentos.

Becerra, A., \& Sánchez, F. (1989). Análisis de las variables implicadas en la detección de la mentira. Revista de Psicología Social, 4, 167-176.

Blanch, J.M., \& Salleras, M. (1990). Perfil psicosocial del demandante de empleo. In J.M. Peiró (Ed.), Trabajo, organizaciones y marketing social (pp. 143-150). Barcelona: PPU.

Blanco, A. (1996). Vygotski, Lewin y Mead: los fundamentos clásicos de la psicología social. In D. Páez \& A. Blanco (Eds.), La teoría sociocultural y la psicología social actual (pp. 27. 62). Madrid: Fundación Infancia y Aprendizaje.

Blanco, A. (1998). La coherencia en los compromisos. Introducción a I. Martín-Baró, Psicología de la liberación. Madrid. Trotta.

Blanco, A. (2000). Aspectos históricos, epistemológicos y metodológicos dela Psicología Social en España. In A. Ovejero (Ed.), La psicología social en España al filo del año 2000: balance y perspectivas (pp. 43-64). Madrid: Biblioteca Nueva, 
Blanco, A., Páez, D., Penín, M., Romo, I., \& Sánchez, F. (1993). Representaciones sobre el SIDA. Estudios empíricos desde la perspectiva de los prototipos. Revista de Psicología de la Salud, I, 123-159.

Carrera, P. \& Fernández-Dols, J.M. (1994). Neutral faces in context: Their emotional meaning and their function. Journal of Nonverbal Behavior, 18, 281-299.

Casas, F. (1989). Situaciones de riesgo en la infancia: la prevención de malos tratos y abandono. INFAD, 2, 69-79.

Casas, F. (1997). Children's rights and children's quality of life: Conceptual and practical issues. Social Indicators Research, 42, 283-298.

Casas, F., \& Durán, S. (1996). Problemas sociales de la infancia y acogimiento familiar como forma de atenderlos: informaciones, representaciones y predisposiciones de la población catalana. Bienestar y Protección Infantil, 2, 23-34.

Chacón, F. (1999). El voluntariado en los programas de intervención social: las repercusiones de la guerra y de la violencia sobre su permanencia. In P. Pérez (Ed.), Actuaciones psicosociales en guerra y violencia política (pp. 243-250). Madrid: Exlibris.

Chacón, F., Menard, M., Sanz, M., \& Vecina, M.L. (1998). Psychosocial factors that influence volunteer work: A pilot study. Psychology in Spain, 2, 108-115.

Chacón, F., \& Vecina, M.L. (1999). Motivaciones y burnout el voluntariado. Intervención Psicosocial, 8, 31-42.

Clemente, M. (1998). La violencia y la delincuencia y la progresión hacia valores individualistas: el delito en función de la evolución de la sociedad española. Sociedad y Utopia, $11,181-198$

Clemente, M., \& Fernández, J. (1994). Los delitos de alta repercusión social: caracterización psicosocial de los delincuentes sexuales. Apuntes de Psicología, 41/42, 29-46.

Clemente, M., \& Vidal, M.A. (1994). La violencia simbólica: la televisión como medio generador de delincuencia en niños. Apuntes de Psicología, 41/42, 47-60.

Corraliza, J.A. (1998). Human behaviour and ecological crisis: Social and psychological dimensions. Bulletin of PeopleEnvironmental Studies, $11,36-40$.

Corraliza, J.A.. \& Aragonés, J.I. (1993). La psicología social y el hecho urbano. Psicothema, 5, 411-426.

Corte, L. de la (1997). Acción y convivencia: algunas implicaciones del pensamiento de Ortega y Gasset para la psicología social y las ciencias humanas. Revista de Historia de la Psicología, 18, 97-102.

Corte, L. de la (1999). La psicología social de Ignacio MartínBaró o el imperativo de la crítica. Estudios Centroamericanos, $613 / 614,975-995$

Domènech, M., \& Ibáñez, T. (1998). La psicología social como crítica. Anthropos, $177,12-21$.

Echebarría, A. (1992). Gender social identity, values and cognitive styles. Revue Intemationale de Psychologie Sociale, 5, 9-20.

Echebarría, A., \& González, J.L. (1993). Social knowledge, identities and social practices. Papers on Social Representations, $2,117-125$.

Echebarría, A., \& Páez, D. (1989a). Emociones: perspectivas emocionales. Madrid: Fundamentos.
Echebarría, A., \& Páez, D. (1989b). Social representation and memory: The case of AIDS. European Journal of Social Psychology, 19, 543-551.

Echebarría, A., San Juan, C., \& Ozmiz, A. (1992). Representations of health, illness and medicines: Coping strategies and health promoting behaviour. British Journal of Clinical Psychology, 31, 339-349.

Falomir, J.M., Mugny, G.. \& Pérez, J.A. (1996). Social influence and threat to identity: Does the fight against tobacco use require a ban on smoking? Revue Intemationale de Psychologie Sociale, 8, 95-108.

Fernández, J. (this issue). Research trends in Spanish psychology (1989-1998).

Fernández-Dols, J.M. (1993). Norma perversa: hipótesis teóricas. Psicothema, 5, 91-101.

Fernández-Dols, J.M., Carrera, P., \& Mallo, M. J. (1989). Expresión facial y contexto: hacia una ecología de la expresión emocional. In A. Echeverría \& D. Páez (Eds.), Emociones: perspectivas psicosociales (pp. 393-429). Madrid: Fundamentos.

Fernández-Dols, J.M., \& Oceja, L. (1994). Efectos cotidianos de las normas perversas en la tolerancia a la corrupción. Revista de Psicologia Social, 9, 3-12.

Fernández-Dols, J.M., \& Ortega, J.E. (1985). Los niveles de análisis de la emoción: James, cien años después. Estudios de Psicología, 21, 35-56.

Fernández-Dols, J.M., Sierra, B., \& Ruiz-Belda, M.A. (1993). On the clarity of expressive and contextual information in the recognition of emotions: A methodological critique. European Joumal of Social Psychology, 23, 195-202.

Fernández-Ríos, M. (1989). Sobre la negociación como proceso de intercambio. Cuadernos Laborales, 15, 52-57.

Fernández-Ríos, M. (1997). Condiciones de éxito-fracaso de la mediación laboral. Revista de Psicología del Trabajo y de las Organizaciones, 12, 221-231.

Fenández-Ríos, M., Rico, R., \& Rascado, R. (1999), De la confrontación al conflicto. Nuevos modelos de gestión del conflicto. In C. Guillén \& R. Gil (Coords.), Psicología del trabajo para las relaciones laborales (pp. 329-352). Madrid; McGraw-Hill.

Fernández-Ríos, M., \& Sánchez-García, J.C. (1997). Eficacia organizacional. Concepto, desarrollo y evaluación. Madrid: Diaz de Santos.

Fernández-Villanueva, C. (1998). Jóvenes violentos. Causas psicosociológicas de la violencia e grupo. Bilbao, Spain: Icaria.

Forteza, J.A., \& Prieto, J. M. (1994). Aging and work behavior. In H.C. Triandis, M. Dunnette, \& L Hough (Eds.), Handbook of Industrial and Organizatioal Psychology (Vol. IV., pp. 447484). Palo Alto, CA.: Consulting Psychologists.

Ganaza, J., Munduate, L., \& Peiró, J. M. (1995). Estilos de gestión del conflicto en las organizaciones. In R. Zurriaga, \& $\mathrm{M}$. Sancerni (Eds.), Experiencias laborales en organizaciones de trabajo (pp. 91-102). Valencia: Nau Llibres.

García Mira, R. (2000). La Psicología ambiental en España. In A. Ovejero (Ed.), La psicología social en España al filo del año 2000: balance y perspectivas (pp. 215-240). Madrid: Biblioteca Nueva. 
Garrido, E. (1995). La psicología de las sentencias judiciales y materia de delitos sexuales. Poder Judicial, 37, 93-139.

Garrido, E., \& Herrero, M.C. (1996). Influence of the persecutor's plead on the judge's sentencing in sexual crimes: Hypothesis of the theory of anchoring by Tversky and Kahneman. In S. Redondo, V. Garrido, J. Pérez, \& Barberet (Eds.), Psychology, law and justice. New developments (pp. 215-222). Berlin: De Gruyter.

Garrido Luque, A., \& Álvaro, J.L. (1992). La auto-estima como reflejo de las transiciones de los jóvenes al mercado de trabajo. Interacción Social, 2, 127-139.

Garzón, A. (1998). Familismo y creencias políticas. Psicología Politica, 17, 101-128.

Gil, F., León, J.M., \& Jarana, L. (1995). Habilidades sociales y salud. Madrid: Pirâmide.

Gil, F., Rodríguez-Mazo, F., \& Alcover, C.M. (1998). Formación de competencias directivas. Revista de Psicología Social, 13, 189-193.

Gil-Monte, P., \& Peiró, J.M. (1998). A study on significant sources of burnout syndrome in workers of occupational centers for the mentally disabled. Psychology in Spain, 1, 116-123.

Gil-Monte, P., Peiró, J.M., \& Valcárcel, P. (1996). Influencia de las variables de carácter sociodemográfico sobre el síndrome de burnout: un estudio en una muestra de profesionales de enfermería. Revista de Psicología Social Aplicada, 6, 43-63.

González, P. (1995). Orientaciones teóricas fundamentales en psicologia de los grupos. Barcelona: EUB.

Gonzälez, P. (1997). Psicología de los grupos. Teoría, investigación y aplicación. Madrid: Síntesis.

González, R., \& Rodríguez, A. (1994). El contenido de los estereotipos y su relación con las teorías implícitas. Psicothema, $6,375-386$.

Gracta, E. (1997). El apoyo social en la intervención comunitaria. Barcelona. Paidós.

Gracia, E., Herrero, J., \& Musitu, G. (1996). Cuestionario de Apoyo Social Comunitario. In J. Herrero, E. Gracia \& G. Musitu (Dirs.), Salud y Comunidad. Evaluación de los recursos y estresores (pp. 206-235). Valencia: CSV.

Gracia, E., \& Musitu, G. (1997). Parental acceptance-rejection, child maltreatment and community social support. Intemational Journal of Child and Family Welfare, 2, 232-246.

Gracia, E., Musitu, G., Arango, G., \& Agudelo, A. (1995). El maltrato infantil. Un análisis desde el apoyo social. Revista Latinoamericana de Psicología, 27, 59-71.

Gracia, F., Ramos, J., \& Peiró, J.M. (1996). Aspectos temporales del trabajo. In J. M. Peiró \& F. Prieto (Eds.), Tratado de psicologia del trabajo. La actividad laboral y su contexto (pp. 125-168). Madrid: Síntesis.

Hernández, B., Correa, P., \& Camacho, J. (1992). Dimensiones en la valoración residencial. Apuntes de Psicología, 1, 91-102.

Hernández, B., \& Suârez, E. (1994). Influencia de las características estructurales en la satisfacción con el barrio. Revista de Psicología Social Aplicada, 4, 87-100.

Herrera, M., \& Reicher, S. (1998). Making sides and taking sides: An analysis of salient images and category constructions for pro and anti-Gulf war respondents. European Journal of Social Psychology, 28, 981-993.
Herrero, J., \& Musitu, G. (1998). Apoyo social, estrés y depresión: un análisis causal del efecto supresor. Revista de Psicología Social, 13, 195-203.

Hontangas, P., Moret, D., Peiró, J.M., \& Balaguer, I. (1990). Autoestima, estatus ocupacional y diferencias sexuales: un estudio longitudinal de los jóvenes en su transición al mercado laboral. In J.M, Peiró (Ed.), Trabajo, organizaciones y marketing social (pp. 159-176). Barcelona: PPU.

Huici, C. (1982). Factores psicosociales en el enfermar humano. In C. Huici (Ed.), Psicología social (pp. 267-289). Unidad Didáctica II Ciencias de la Conducta. Curso Nivelación ATS. Madrid: UNED.

Huici, C., \& Ros, M. (1993). Identidad comparativa y diferenciación intergrupal. Psicothema, 5, 225-236.

Ibáñez, T. (1990). Aproximaciones a la psicología social. Barcelona: Sendai.

Ibáñez, T. (1994). Psicologia social construccionista. México: University of Guadalajara.

Ibán̆ez, T. (1997). Why a critical social psychology? In T. Ibáñez \& L. Îniguez (Eds.), Critical social psychology (pp. 27.41). London: Sage.

Ibáñez, R., \& Íñiguez, L. (1996). Aspectos metodológicos de la psicología social aplicada. In J.L. Álvaro, A. Garrido, \& J.R. Torregrosa (Eds.), Psicología social aplicada (pp 57-82). Madrid: McGraw-Hill.

Itza, L., Pinilla, P., \& Páez, D. (1987). Representación social de la enfermedad física y mental. In D. Páez (Ed.), Pensamiento, individuo y sociedad. Cognición y representación social (pp. 318-346)). Madrid: Fundamentos.

Javaloy, F., Cornejo, J.M., \& Bechini, A. (1990). España vista desde Cataluña: estereotipos étnicos en una comunidad plural. Barcelona: PPU.

Jiménez Burillo, F. (1976). La psicología social en España. Notas para una historia de las ciencias sociales. Revista de Psicologia General y Aplicada, 31, 235-284.

Jiménez Burillo, F. (1997). Notas sobre la fragmentación de la razón. Madrid: Universidad Complutense de Madrid.

Jiménez Burillo, F., \& Aragonés, J.I. (1986). Introducción a la psicología ambiental. Madrid: Alianza Editorial.

León, J.M., Jarana, L., \& Blanco, A. (1991). Entrenamiento en habilidades sociales al personal de enfermería: efectos sobre la comunicación con el usuario de los servicios de salud. Clínica y Salud, 2, 73-79.

León, J.M., \& Medina, S. (1994). Evaluación de habilidades para la vida en niños con ceguera congénita. Revista de Psicología de la Salud, 6, 3-33.

Leôn, J.M., Medina, S., Cantero, F., Gómez, T., Barriga, S., Gil, F., \& Loscertales, F. (1997). Habilidades de información y comunicación en la atención al usuario. Sevilla: Servicjo Andaluz de Salud.

López, M. (1993). Tipicidad de identidad de género y comparación intergrupal. Revista de Psicología Social, 8, 189-200.

López, M. (1994). Procesos culturales e individuales implicados en la estereotipia de género. Una aproximación empírica en la elección de carrera. Revista de Psicología Social, 9, 213-230. 
López, S., Sánchez, S., Pastor, M. A., \& Rodríguez-Marín. J. (1990). Apoyo social en cirugía: un estudio con pacientes con desprendimiento de retina. II/ Congreso de Psicología Social. Libro de Simposios. Santiago de Compostela.

López-Yarto, L. (1997). Dinámica de grupos. Cincuenta años después. Bilbao, Spain: Desclée de Brouwer.

López-Zafra, E., \& Morales, J.F. (1999). Niveles de análisis en el estudio del liderazgo. Revista de Psicología Social, 14, 181 198.

Marqués, J., Abrams, D., Páez, D., \& Martínez-Taboada, C. (1998). The role of categorization and in-group norms in judgements of groups and their members. Joumal of Persondity and Social Psychology. 75, 976-988.

Martín, A., \& Martínez, J.M. (1998). Prevención en dependencias. Un programa comunitario. In A. Martín (Coord.), Psicología comunitaria, findamentos y aplicaciones (pp. 325-358). Madrid: Síntesis.

Martín, A., Martínez, J.M., \& López, J. (1995). La donación en España: un estudio de sus aspectos psicosociales. In R. Matesanz \& A. Miranda (Eds.), Coordinación y trasplante. El modelo español (pp. 143-160). Madrid: Aula Médica.

Martín, A., Martínez, J.M., López, J., Martín, M.J., \& Martín, J.M. (1998). Comportamiento de nesgo: violencia, prácticas sexuales de riesgo y consumo de drogas ilegales en la juventud. Madrid: Entinema.

Martín, A., Martínez, J.M., \& Manrique, S. (1991). Donación de órganos para trasplantes. Aspectos psicosociales. Nefrologia, $I I, 62-69$.

Medina, S., \& León, J. M. (1995). Entrenamiento en habilidades sociales a nin̆os con ceguera congénita. In F. Gil, J. M León, \& L. Jarana (Coords.), Habilidades sociales y salud (pp. 147168). Madrid: Pirámide.

Melíá, J.L., Arnedo, M.T., \& Ricarte, J.J. (1996). Efecto experimental del modelado de la conducta segura y del refuerzo de la conducta productiva sobre la seguridad y la productividad. Psicológica, 17, 229-248.

Meliá, J.L., Sospedra, M.J., \& Rodrigo, M.F. (1994). Medición del riesgo basal (RB3/17) en psicología de la seguridad laboral. Amuario de Psicología, 60, 49-61.

Morales, J.F., \& López, M. (1994). Estereotipos de género y valores. In M. Älvaro (Ed.), Propuesta de un sistema de indicadores sociales de igualdad entre géneros (pp. 375-400). Madrid: Ministerio de Asuntos Sociales.

Morales, J.F., \& Molero, F. (1995). El liderazgo en los equipos de atención primaria. Cuadernos de Gestión, 1, 83-91.

Moreno, F. (1991). Infancia y guerra en Centroamérica. San José, Costa Rica: Flacso.

Morera, D., \& Rodríguez, A. (1994). La relación entre actitudes y teorías implícitas: su estudio en situaciones de conflicto intergrupo. Psicothema, 6, 215-227.

Morera, D., \& Rodríguez, A. (1997). El efecto de la variablidad de la información categorial sobre la memoria estereotípica. Revista de Psicologia Universitas Tarraconensis, XIX, 89-104.

Moscovici, S., \& Pérez, J.A. (1997). Representations of society and prejudice. Papers on Social Representations, 6, 27-36.
Munduate, L., Ganaza, J., \& Alcaide, M. (1993). Estilos de gestión del conflicto interpersonal en las organizaciones. Revista de Psicología Social, 8, 47-68.

Munduate, L., Luque, P., \& Barón, M. (1998). Styles of handling interpersonal conflict: An observational study. Psicothema, 9 , 145-153.

Mugny, G., Sánchez-Mazas, M., Roux, P., \& Pérez, J.A. (1991). Independence and interdependence of group judgments: Xenophobia and minority influence. European Joumal of Social Psychology. 21, 213-223.

Munné, F. (1997). Plumalismo teórico y comportamiento social. Psicología y Sociedad, 9, 31-46.

Munné, F. (1999). Constructivismo, construccionismo y complejidad: la debilidad de la crítica en la psicología construccional. Revista de Psicología Social, 14, 131-144.

Negrillo, C., Tirado. A., \& León, J.M. (1994), Habilidades sociales. Entrenamiento en una escuela de enfermería. Rol (Revista de Enfermería), 188, 26-29.

Ojeda, M., Pérez, A., Jarana, L., \& León, J.M. (1989). Diseño. implantación y evaluación de un programa de entrenamiento en habilidades sociales a deficientes mentales institucionalizados. Revista Española de Terapia del Comportaniento, 7, 183-197.

Osca, A., Alonso, E., \& Palací, F.J. (1995). La cultura organizacional de los Equipos de Atención Primaria (EAPs) y de los Centros de Atención a Drogodependientes (CADs). In R. Zurriaga \& M.D. Sancerni (Eds.), Experiencias laborales en organizaciones de trabajo (pp. 49-64). Valencia: NAU Llibres.

Ovejero, A. (1991). Algunas consideraciones sobre la "crisis" de la psicología social. Causas, consecuencias y tendencias futuras. Interacción Social, I, 169-184.

Ovejero, A. (1992). Algunas consideraciones sobre la psicosociología de Ortega. Interacción Social, 2, 85-108.

Ovejero, A. (1996). Aprendizaje cooperativo: una altemativa eficaz a la enseñanza tradicional. Barcelona: PPU.

Ovejero, A. (1997, September). Identidad y diversidad: ¿qué es realmente el nacionalismo? Vl Congreso de Psicología Social. San Sebastián.

Páez, D., \& Adriân, J.A. (1993). Arte, lenguaje y emoción: perspectivas vygotskyanas sobre las emociones. Madrid: Fundamentos.

Páez, D., Arróspide, J., Martinez-Taboada, C., \& Ayestarán, S. (1992). Identidad social, autoesquematización y autoconciencia colectiva. Revista de Psicología Social. Monográfico, 3-20.

Páez, D., Echebsuria, A., Valencia, J.F., Romo, I., San Juan, C., \& Vergara, A. (1991a). AIDS social representations: Contents and proceses. Joumal of Community and Applied Psychology, 1, 89-104.

Páez, D., Insúa, P., \& Vergara, A. (1992). M. Halbwachs y la memoria colectiva: la imagen histórica de Europa como un problema psicosocial. Interacción Social, 2, 109-126.

Páez, D., San Juan, C., Romo, I., \& Vergara, A. (1991). SIDA: imagen y prevención. Madrid: Fundamentos.

Páez, D., Ubillos, S., \& León, M. (1996). Evaluación del cambio de actitudes y conducta ante el SIDA. In N. Basabe, D. Páez. R. Usieto, H. Paicheler, \& J.C. Deschamps, El desafio sucial del SIDA (pp. 113-133). Madrid: Fundamentos. 
Páez, D., Ubillos, S., \& Paichelier, H. (1994). Representaciones sociales del SIDA: una revisión empírica y teórica. Publicación Oficial de SEISIDA, 5, 6-13.

Páez, D., \& Vergara, A. (1995). Cultural differences in emotional knowledge. In J. RusselI, J.M. Fernández-Dols, A.S. Manstead, \& J.C. Wellemkamp (Eds.), Everyday conceptions of entotions (pp. 415-434). London: Kluwer Academic Press.

Palací, F. J., Osca, A., Grau, R., \& Bravo, M.J. (1995). Tácticas de socialización organizacional organizacional e innovación de rol. In R. Zurriaga \& M.D. Sancerni (Eds.), Experiencias laborales en organizaciones de trabajo (pp. 41-49). Valencia: NAU Llibres.

Palací, F.J., Osca, A., \& Ripoll, P. (1995). Tácticas de socialización organizacional y estrés de rol durante la primera experiencia laboral. Revista de Psicología del Trabajo y de las Organizaciones, $11,19-33$.

Pastor, M.A., García-Hurtado, J., López, S., Pascual, E., Rodríguez Marín J., \& Salas, E. (1989). Ansiedad y dolor en pacientes reumáticos. Revista de Psicología de la Salud, 1, 51-64.

Pastor, M.A., López, S., Rodríguez-Marín, J., Terol, M.C., \& Sánchez, S. (1995). Evaluación multidimensional del dolor crónico en enfermos reumáticos. Revista de Psicología de la Salud, 7, 79-106.

Pastor, M.A., López, S., Salas, E., Sánchez, S., Terol, M.C., \& Rodríguez-Marín, J. (1994). El papel del apoyo social en la experiencia del dolor crónico. Un estudio empírico. Revista de Psicologia Social, 9, 179-191.

Pastor, M.A., Rodríguez-Marín, J., López, S., Sánchez, S., Salas, E. \& Pascual, E. (1990). Afrontamiento del dolor crónico en pacientes reumáticos. In COP (Ed.), Psicología de la salud (pp. 35-60). Madrid: COP.

Pastor, M.A., Salas, E., López, S., Rodríguez-Marín, J., Sánchez, S., \& Pascual, E. (1993). Patients' beliefs about their lack of pain control in primary fibromyalgia syndrome. Journal of Reumathology, 32, 484-489

Paúl, P. de (1996), El tribunal del jurado desde la psicología social. Barcelona: PPU.

Pennebaker, J., Páez, D., \& Rimé, B. (1997). Collective memory of political events. Hillsdale, $\mathrm{NJ}$ : Erlbaum.

Peiró, J.M., \& González, V. (1990). Clima y satisfacción laboral en los equipos de atención primaria. Valencia: Nau Llibres y Generalitat Valenciana.

Peiró, J.M., González, V., Zurriaga, R., Ramos, J., \& Bravo, M.J. (1990). El Cuestionario de Satisfacción Laboral de Profesionales de la Salud de Equipos de Atención Primaria (CSLPS-EAP). Revista de Psicología de la Salud, 1, 135-174.

Peiró, J.M., \& Munduate, L. (1999). Psicología del trabajo y de las organizaciones en España en la década de los noventa. Revista de Psicología General y Aplicada, 52, 371-428.

Peiró, J.M., \& Ramos, J. (1995). La gestión de instalaciones deportivas. Una perspectiva psicosocial. Valencia: Nau Llibres.

Peiró, J.M., Ramos, J., González, P. Rodríguez, I., Tordera, N., \& Martínez-Tur, V. (1997). La distinción entre organizaciones públicas y privadas: diferencias en la gestión de instalaciones deportivas. Revista de Psicología del Trabajo y de las Organizaciones, $1,27-50$.
Pérez, J.A., Falomir, J.M., \& Mugny, G. (1995). Internalization of conflict and attitude change. European Journal of Social Psychology, 25, 117-124.

Pérez, J.A., \& Mugny, G. (1988). Psicología de la influencia social. Valencia: Promolibro.

Pérez, J.A., \& Mugny, G. (1990). Changement d'attitude, crédibilité et influence minoritaire: Interdépendence et indépendence de la comparaison sociale. Revue Suisse de Psychologie, 45, 155-163.

Pérez, J.A., \& Mugny, G. (1992). Social impact of experts and minorities, and smoking cessation. Swiss Monographs in Psychology: 1, 184-188.

Pinillos, J.L. (1965). La psychologie sociale en Espagne. Social Sciences, 4, 23-39.

Pol, E., \& Moreno, E. (1994). Evaluación del impacto social en los estudios de impacto ambiental: propuesta de una guía metodológica. In B. Hernández, J. Martínez, \& E. Suárez (Eds.), Psicología ambiental y responsabilidad ecologica (pp. 82-105). Las Palmas: Universidad de Las Palmas.

Pol, E., \& Vidal, T. (Eds.). (1996). Perfils socials en la intervenció ambiental. Una perspectiva profesional. Monografias psicosocio-ambientals $\left(N^{\circ} 1\right)$. Universitat de Barcelona.

Prieto, J.M. (1993). The team perspective in selection and assessment. In H. Schuler, J.L. Farr, \& M. Smith (Eds.), Personnel selection and assessment (pp. 221-234). Hillsdale, NJ: Erlbaum

Prieto, J.M., \& Simón, C. (1997). Network and its implications for assessment. In N. Anderson \& P. Herriot, (Eds.), International handbook of selection and assessment (pp. 97124). Chichester, UK: Wiley.

Prieto, J.M., Zornoza, A., \& Peiró, J.M. (1997). Nuevas tecnologias de la información en la empresa. Madrid: Pirámide.

Ramos, J., Peiró, J.M., \& González, P. (1993). Gestión de instalaciones deportivas: influencia sobre la satisfacción con el uso de actividades. Revista de Psicología Social Aplicada, 2, 73-88.

Rodríguez, A. (1994). El conflicto intergrupal desde las teorías implícitas. In M.J. Rodrigo, A. Rodríguez, \& J. Marrero (Coords.) Las teorias implícitas. Una aproximación al conocimiento cotidiano (pp. 309-337). Madrid: Visor.

Rodríguez, A. (1990). La cultura en la organización. Revista Internacional de Sociología, 48, 63-90.

Rodríguez, A. (1993). La cultura en las organizaciones públicas y privadas. Psicothema, 5, 237-260.

Rodríguez, D., \& Serrano, G. (1991). Análisis de las características psicométricas y estructura factorial del Cuestionario de Actitudes hacia la Negociación (CAN). Revista de Psicología del Trabajo y de las Organizaciones, 18, 34-48.

Rodríguez, M.S., Sabucedo, J.M., \& Arce, C. (1991). Estereotipos regionales y nacionales; del conocimiento individual a la sociedad pensante. Revista de Psicología Social, 6, 2-22.

Rodríguez-Marín, J., López, S., \& Pastor, M.A. (1989). Estrés por hospitalización y estrategias de afrontamiento. Revista de Psicología de la Salud, I, 81-104.

Rodríguez-Marín, J., Pastor, M.A., \& López, S. (1993). Afrontamiento, apoyo social, calidad de vida y enfermedad. Psicothema, 5, 349-372. 
Ros, M., Azurmendi, M.J., Bourhis, R., \& García, I. (1999). Identidades culturales y lingüísticas en las Comunidades Autónomas bilingües de España: antecedentes y consecuencias. Revista de Psicología Social, 14, 69-86.

Ros, M., Cano, I., \& Huici, C. (1987). Language and intergroup perception in Spain. Journal of Language and Social Psychology, 6, 243-259.

Ros, M., Huici, C., \& Cano, I. (1990). Categorización lingüíistica, identidad social y atribución social. In G. Musitu (Ed.), Procesos psicosociales básicos I (pp. 50-72). Barcelona: PPU.

Rosa, A., Blanco, F., Travieso, D., \& Huertas, J.A. (1999). Argumentando sobre el cambio histórico. Explicaciones sobre el pasado, el presente y el fururo de España. Psicología Política, 18, 49-75.

Rosa, A., Huertas, J.A., \& Blanco, F. (1996). Metodologia para la historia de la Psicología. Madrid: Alianza.

Roux, P., Mugny, G., \& Pérez, J.A. (1989). Conflit, degré de résistence, et influence minoritaire. Bulletin de Psychologie, 42, 788-795.

Russell, J., \& Fernádez-Dols, J.M. (Eds.). (1997). The psychology of facial expression. Cambridge, UK: Cambridge University Press.

Sabucedo, J.M. (1989). Factores psicosociales asociados a las formas de participación política institucional y no institucional. In M. Villarreal (Comp.), Movimientos sociales (pp. 195-208). Zarautz, Spain: Servicio Editorial Universidad del País Vasco.

Sabucedo, J.M. (2000). Algunas consideraciones sobre la evolución y desafíos de la psicología política española. In A. Ovejero (Ed.), La psicología social en España al filo del año 2000: balance y perspectivas (pp. 183-198). Madrid: Biblioteca Nueva.

Sabucedo, J.M., Arce, C., \& Rodríguez, M.S. (1992). Xuventude e política en Galicia. Santiago de Compostela, Spain: Servicio de Publicaciones de la Universidad de Santiago de Compostela.

Sabucedo, J.M., \& Fernández, C. (1998). Nacionalismos e ideología. Un análisis psicosocial. Revista de Psicología Política, 17, 7-19.

Sabucedo, J.M., Grossi, J,, \& Fernández, C. (1998). Los movimientos sociales y la creación de un sentido común alternativo. In P. Ibarra \& B. Tejerina (Eds.), Los movimientos sociales. Transformaciones politicas y cambio cultural (pp. 165-180). Madrid: Trotta,

Salgado, J. (1997). The five factor model of personality and job performance in the European Community (EC). Journal of Applied Psychology, 82, 30-43.

Salgado, J. (1998). Sample size in validity studies of personnel selection. Journal of Occupational and Organizational Psychology, 71, 161-164.

Salgado, J., \& Rumbo, A. (1997). Personality and job performance in financial services managers, International Journal of Selection and Assessment, 5, 91-100.

Sánchez, F., Becerra, A., Caballero, A., \& Amate, M. (1995). Incidencia de la prototipicidad de los mensajes sobre la detección experimental de la mentira. Revista de Psicología Social, 10, 31-41.

Sánchez, F., Romo, l., Páez, D., Blanco, A., \& Lalljee, M. (1996). Aportaciones del concepto de prototipo en la investigación sobre el SIDA. Implicaciones y limitaciones. In N. Basabe, D.
Páez, R. Usieto, H. Paicheler, \& J.C. Deschamps (Eds.), El desafio social del SIDA (pp. 175-192). Madrid: Editorial Fundamentos.

Sánchez, F., Rubio, J., Páez, D., \& Blanco, A. (1998). Optimismo ilusorio y percepción de riesgo. Boletín de Psicología, 58, 7-17.

Sánchez-Miguel, E., \& García-Sánchez, J.N. (this issue). The decade 1989-1998 in Spanish psychology: An analysis of research in Developmental and Educational Psychology.

Sangrador, J.L. (1996). Identidades, actitudes y estereotipos en la España de las Autonomias. Madrid: CIS.

Sanz, J. (this issue). The decade 1989-1998 in Spanish psychology: An analysis of research in Personality, Assessment, and Psychological Treatment (Clinical and Health Psychology).

Serrano, G., \& Remeseiro, C. (1990). Actitudes ante la negociación laboral. In J. Seoane (Ed.), Psicología politica de la sociedad contemporánea (pp. 105-130). Valencia: Promolibro.

Silva. M. (1992). El clima en las organizaciones. Barcelona: PPU Silva, M. (1994). Intervención sobre el clima organizacional, In J. M Peiró \& J. Ramos (Eds.), Intervención psicosocial en las organizaciones (pp. 515-542). Barcelona: PPU.

Sobral, J. (1994). Pricología y ley. Un exámen de las decisiones juridicas. Madrid: Eudema.

Sobral, J., Arce, R., Fariña, F., \& Vilán, V. (1991). Influencia de la ideología sobre el proceso de discusión y toma de decisiones de los jurados legos. Anuario de Psicología Jurídica, 1,159 172.

Sobral, J., \& Prieto, A. (1993). Persuasión y testificación: una revisión social de la credibilidad del testimonio. Psicothema, 5, 393-410.

Torre, A. de la (1997). Cambio tecnológico: factores críticos y preventivos en el comportamiento laboral. Revista de Psicología del Trabajo y de las Organizaciones, 13, 51-64.

Torre, A. de la (1998). El desafio del cambio tecnológico. Hacia una mueva organización del trabajo. Madrid: Tecnos.

Torregrosa, J.R. (1971). Actitudes intergeneracionales. Hacia una nueva conciencia política en España. Revista de Estudios Sociales, 2, 75-102.

Torregrosa, J.R. (1985). Ortega y la psicología social histórica. Revista de Psicología Social, 0, 55-56.

Torregrosa, J.R. (1996). Concepciones del aplicar. In J.L. Álvaro, A. Garrido \& J.R. Torregrosa (Eds.), Psicología social aplicada (pp. 39-56). Madrid: McGraw-Hill,

Valencia, J. (1990). La lógica de la acción colectiva: tres modelos de análisis de la participación política no institucional. Revista de Psicologia Social, 5, 185-214.

Valencia, J., \& Villarreal, M. (1992). El conflicto político en Euskadi: un enfoque psicosocial de la participación política no institucional. Revista de Psicología Política, 5, 7-26.

Vivas, J., Muñoz, J., \& Íñiguez, L. (1997, September). El nacionalismo catalán. Un estudio histórico y psicosocial, VI Congreso Nacional de Psicología Social. San Sebastián.

Zurriaga, R., Bravo, M.J., \& Peiró, J.M. (1990). La satisfacción laboral en profesionales sanitarios de organizaciones públicas y privadas. Revisia de Psicología del Trabajo y de las Organizaciones, 6, 67-73. 